OPEN ACCESS

Edited by:

Gillberto Igrejas,

University of Trás-os-Montes and Alto

Douro, Portugal

Reviewed by:

Jose Luis Balcazar,

Catalan Institute for Water Research,

Spain

Elaine Allan,

University College London, UK Christopher Morton Thomas,

University of Birmingham, UK

${ }^{*}$ Correspondence: Petra F. G. Wolffs p.wolff@@mumc.nl

Specialty section

This article was submitted to Antimicrobials, Resistance and Chemotherapy,

a section of the journal

Frontiers in Microbiology

Received: 30 October 2015 Accepted: 01 February 2016 Published: 19 February 2016

Citation:

von Wintersdorff CJH, Penders J, van Niekerk JM, Mills ND, Majumder S, van Alphen $L B$, Savelkoul PHM and Wolffs PFG (2016) Dissemination of Antimicrobial Resistance in Microbial Ecosystems through Horizontal Gene

Transfer. Front. Microbiol. 7:173. doi: 10.3389/fmicb.2016.00173

\section{Dissemination of Antimicrobial Resistance in Microbial Ecosystems through Horizontal Gene Transfer}

\author{
Christian J. H. von Wintersdorff ${ }^{1}$, John Penders ${ }^{1,2}$, Julius M. van Niekerk ${ }^{2}$, \\ Nathan D. Mills ${ }^{1}$, Snehali Majumder ${ }^{2}$, Lieke B. van Alphen ${ }^{2}$, Paul H. M. Savelkoul ${ }^{1,2,3}$ and \\ Petra F. G. Wolffs ${ }^{1,2 *}$
}

' Department of Medical Microbiology, NUTRIM School for Nutrition and Translational Research in Metabolism, Maastricht University Medical Center+, Maastricht, Netherlands, ${ }^{2}$ Department of Medical Microbiology, Caphri School for Public Health and Primary Care, Maastricht University Medical Center+, Maastricht, Netherlands, ${ }^{3}$ Department of Medical Microbiology and Infection Control, VU University Medical Center, Amsterdam, Netherlands

The emergence and spread of antibiotic resistance among pathogenic bacteria has been a rising problem for public health in recent decades. It is becoming increasingly recognized that not only antibiotic resistance genes (ARGs) encountered in clinical pathogens are of relevance, but rather, all pathogenic, commensal as well as environmental bacteria-and also mobile genetic elements and bacteriophages-form a reservoir of ARGs (the resistome) from which pathogenic bacteria can acquire resistance via horizontal gene transfer (HGT). HGT has caused antibiotic resistance to spread from commensal and environmental species to pathogenic ones, as has been shown for some clinically important ARGs. Of the three canonical mechanisms of HGT, conjugation is thought to have the greatest influence on the dissemination of ARGs. While transformation and transduction are deemed less important, recent discoveries suggest their role may be larger than previously thought. Understanding the extent of the resistome and how its mobilization to pathogenic bacteria takes place is essential for efforts to control the dissemination of these genes. Here, we will discuss the concept of the resistome, provide examples of HGT of clinically relevant ARGs and present an overview of the current knowledge of the contributions the various HGT mechanisms make to the spread of antibiotic resistance.

Keywords: antibiotic resistance, resistome, transformation, conjugation, transduction, gene transfer agents, GTA, lateral gene transfer

\section{INTRODUCTION}

The ever-increasing magnitude of antimicrobial resistance (AMR) encountered in human pathogens is a huge concern for public health worldwide, limiting treatment options for bacterial infections and thereby reducing clinical efficacy while increasing treatment costs and mortality. With a lack of development of new antibiotics, and increasing resistance even to last-resort antibiotics (Nordmann et al., 2012), there is a need to conserve the ones available.

Natural antibiotics have existed for billions of years (Barlow and Hall, 2002; Hall and Barlow, 2004; Bhullar et al., 2012; Wright and Poinar, 2012), providing a selective benefit for the producing strains by inhibiting or eliminating other bacteria competing for resources (Martinez, 2008; Aminov, 2009). Additionally, their function as cell-cell signaling molecules has been described 
(Davies, 2006; Linares et al., 2006). Just as antibiotics are ancient, so are antibiotic resistance genes (ARGs), as evidenced by studies identifying various ARGs in ancient permafrost samples (D'Costa et al., 2011; Perron et al., 2015) and isolated cave microbiomes (Bhullar et al., 2012). Resistance to antibiotics can occur either by mutations or by acquisition of resistance conferring genes via horizontal gene transfer (HGT), of which the latter is considered to be the most important factor in the current pandemic of AMR.

The HGT of ARGs also far predates the production and use of antibiotics by humans. For example, OXA-type $\beta$-lactamases were found to be plasmid-borne and able to transfer between bacterial species millions of years ago (Barlow and Hall, 2002). However, while antibiotic resistance and its spread by HGT are ancient mechanisms, the rate at which these processes occur and the number of resistant strains has increased tremendously over the past few decades because of selective pressure through human antibiotic use.

\section{THE GLOBAL ANTIBIOTIC SELECTION PRESSURE}

While the discovery of antibiotics revolutionized the field of medicine, their increasingly large-scale production and consumption has had widespread effects on the microbial biosphere. In their analysis, Van Boeckel et al. showed that global human antibiotic consumption amounted to 54,083,964,813 standard units (pills, capsules, or ampoules) in 2000 and had increased by $36 \%$ to $73,620,748,816$ standard units by 2010 (Van Boeckel et al., 2014). The same authors estimated that antibiotic consumption in food animals, which is assumed to be larger than that of humans, was over 63 million $\mathrm{kg}$ in 2010 and will also drastically increase in the coming years (Van Boeckel et al., 2015) despite recent initiatives to reduce antibiotic use in animals. Such high and continuously increasing amounts of antibiotics overwhelm the natural production, causing a constantly increasing selection pressure on bacterial populations in all exposed environments.

The use and misuse of antibiotics in medicine, agriculture, and aquaculture has been linked to the emergence of resistant bacteria in these settings (Cabello, 2006; Penders and Stobberingh, 2008; Economou and Gousia, 2015). However, the impact of antibiotic usage extends further, as antibiotic residues, resistant bacteria, and genetic resistance elements subsequently spread to adjacent environments. The majority of consumed antibiotics are excreted unchanged (Sarmah et al., 2006) and are then introduced into the environment directly or through waste streams. Such waste streams, as well as wastewater treatment plants, are considered to be hotspots for the dissemination of AMR, since resistance genes, mobile genetic elements (MGEs), and (sub-inhibitory) antibiotic selection pressure from various sources are introduced to commensals and pathogens (Tennstedt et al., 2003; Martinez, 2009; Zhang et al., 2009; Graham et al., 2011). Moreover, the antibiotic compounds are often not completely removed in treatment plants (Watkinson et al., 2007; Le-Minh et al., 2010), from where they then disseminate further. A study by Larsson et al. showed that a treatment plant in India, receiving water from drug manufacturing sites, exposes its direct environment to very high levels of antibiotics, discharging $\sim 45 \mathrm{~kg}$ of ciprofloxacin per day (Larsson et al., 2007), contaminating surface, ground, and drinking water in the area (Fick et al., 2009). As a result, not only were highly multiresistant bacteria found to be common within the treatment plant (Marathe et al., 2013), but high levels of ARGs and MGEs were also detected in nearby river sediments (Kristiansson et al., 2011).

How environmental exposure to antibiotics contributes to the selection of resistant strains and the increase of resistome elements is illustrated by a study comparing soil samples taken between 1940 and 2008, which shows that ARGs from all classes of antibiotics tested ( $\beta$-lactams, tetracyclines, erythromycins, and glycopeptides) significantly increased since 1940, with a tetracycline ARG being over 15 times more abundant than in the 1970s (Knapp et al., 2010). Moreover, the increasing selection pressure has altered bacterial HGT processes, increasing the number of resistome elements which reside on mobile DNA compared to the pre-antibiotic era (Datta and Hughes, 1983).

\section{RESERVOIRS OF RESISTANCE}

In order to understand the dissemination of antibiotic resistance, it is necessary to map the resistome of various environments, and to unravel to what extend these environments can act as a reservoir for the dissemination of ARGs to bacterial pathogens. In recent years there has been increasing interest in this matter, as many studies have used various techniques to sample the resistome of environments such as, but not limited to, soil, wastewater, and human and animal gut microbiota (Pehrsson et al., 2013; Penders et al., 2013; Rizzo et al., 2013; von Wintersdorff et al., 2014). It has since become clear that ARGs, including clinically relevant ones, are widespread in such environments (Wright, 2010). Studies applying a metagenomic approach directly recover DNA from all microorganisms in a biological sample, thereby avoiding the bias that is introduced when selecting certain organisms, and allowing for the investigation of the resistome of microbial ecosystems. The sequencing of metagenomes from various environments has led to a wealth of data which is often publicly available in databases. Such databases can be mined for the presence of resistance genes, even when the initial studies did not focus specifically on ARG content in these metagenomes. For example, mining such metagenomic databases for the plasmid-mediated colistin resistance gene $m c r-1$, which has recently been discovered in clinical and commensal isolates (Arcilla et al., 2015; Liu et al., 2015), has revealed that this gene had already spread to the human gut microbiome of Chinese subjects several years ago (Hu et al., 2015). While sequence based studies provide huge amounts of data, they are limited to either identifying genes that are already known, or to predicting novel sequence functions based on high homology to known sequences. Annotation by sequence-based studies will keep increasing however, as studies using functional metagenomics keep identifying novel ARGs. An increasing number of such studies have revealed a huge number of previously unknown ARGs present in environments such as soil (Riesenfeld et al., 2004; D’Costa et al., 2006; Allen et al., 2009; 
Donato et al., 2010; Torres-Cortes et al., 2011; Perron et al., 2015) or activated sludge (Mori et al., 2008; Parsley et al., 2010), as well as in the microbiota of animals (Kazimierczak et al., 2009; Wichmann et al., 2014) and humans (Sommer et al., 2009; Cheng et al., 2012; Moore et al., 2013, 2015; Card et al., 2014; Fouhy et al., 2014; Clemente et al., 2015).

Recent metagenomic studies have also uncovered that ARGs predominantly cluster by ecology, implying that the resistome in soils, and wastewater treatment plants differ significantly from that of human pathogens (Gibson et al., 2015; Munck et al., 2015). Nonetheless, the authors of these works note that parts of these resistomes are shared (Forsberg et al., 2012) and stress the importance of continuing the exploration of the resistome of such environments.

That commensals and the environment are important reservoirs for resistance is supported by several examples of ARGs on MGEs in human pathogens that appear to have originated from those reservoirs. A well-known example is that of the bla $a_{\mathrm{CTX}}-\mathrm{M}$ genes, which have become the most prevalent cause of extended-spectrum $\beta$-lactamases (ESBLs) in Enterobacteriaceae worldwide and a major cause of clinical treatment problems (Hawkey and Jones, 2009). The potential origin of these genes was identified as the chromosomal DNA of various environmental Kluyvera species, from where they spread very successfully to different bacterial species (Canton and Coque, 2006). Shewanella algae, a marine and freshwater species, was found to be the origin of plasmid-encoded $q n r A$ genes, conferring quinolone resistance (Poirel et al., 2005a), and different Vibrionaceae species might be the reservoir for other plasmid-encoded qnr genes (Poirel et al., 2005b), which have disseminated globally in various Enterobacteriaceae species, with exceptionally high prevalence rates in some areas (Vien le et al., 2012). The OXA-48-type carbapenem-hydrolyzing $\beta$-lactamase genes, which are increasingly reported in enterobacterial species worldwide, were also found to originate from the chromosomes of waterborne, environmental Shewanella species (Poirel et al., 2012). As with these few examples, many clinically relevant resistance genes are believed to have originated from nonpathogenic bacteria, highlighting the immense potential of HGT for these pathogens in overcoming human use of antibiotics.

\section{CONTRIBUTION OF THE VARIOUS HGT MECHANISMS TO THE SPREAD OF ARGS}

\section{Conjugation}

Conjugation is the transfer of DNA through a multi-step process requiring cell to cell contact via cell surface pili or adhesins. It is facilitated by the conjugative machinery which is encoded either by genes on autonomously replicating plasmids or by integrative conjugative elements in the chromosome (Smillie et al., 2010; Wozniak and Waldor, 2010). Additionally, this conjugative machinery may enable the mobilization of plasmids that are non-conjugative, as observed for e.g., the exceptionally broad host range IncQ plasmids (Meyer, 2009). Of the various mechanisms that may facilitate HGT (Figure 1), conjugation is certainly the most commonly studied (Norman et al., 2009; Guglielmini et al., 2013).

ARGs are in many cases associated with conjugative elements such as plasmids or transposons. While the transfer of these elements may also occur through transformation or transduction, conjugation is often considered as the most likely responsible mechanism. This is due to the fact that it provides better protection from the surrounding environment and a more efficient means of entering the host cell than transformation, while often having a broader host range than bacteriophage transduction. Moreover, while conjugation is a process directed toward the transfer of bacterial genes, transfer of bacterial DNA by transduction is a side-effect of erroneous bacteriophage replication (Norman et al., 2009).

The conjugation of MGEs conferring AMR has been observed in many types of ecosystems, ranging from transfer between bacteria in insects, soil, and water environments to various food and healthcare associated pathogens (Davison, 1999). Importantly, transfer of plasmids and conjugative transposons, such as those of the Tn916 family, between unrelated bacteria over large taxonomic distances has been described (Shoemaker et al., 2001; Musovic et al., 2006; Roberts and Mullany, 2009; Tamminen et al., 2012), indicating that this mechanism contributes significantly to the dissemination of ARGs between different reservoirs via such broad host range MGEs.

The spread of antibiotic resistance plasmids in human pathogens is especially well studied, and shows that once resistance genes have become established on successful plasmids, they may rapidly spread across different strains, species, or even genera. This is well demonstrated by the bla $a_{\mathrm{CTX}-\mathrm{M}} \mathrm{ESBL}$ genes, which have disseminated to various narrow and broad host range plasmids within Enterobacteriaceae, as well as to other opportunistic human pathogens (Canton et al., 2012). These genes are now ubiquitous in humans (Woerther et al., 2013), animals, and the environment (Hartmann et al., 2012). Furthermore, the transfer of plasmids in pathogens has led to the worldwide spread of numerous ARGs encoding resistance to $\beta$-lactams, quinolones, aminoglycosides, tetracyclines, sulfonamides, and many other drug classes (Huddleston, 2014). Of particular concern is the increasingly reported spread of plasmids harboring carbapenem resistance (Carattoli, 2013) and the recent discovery of plasmid-encoded colistin resistance in China (Liu et al., 2015), which has now already been identified at multiple continents (Arcilla et al., 2015) and may cause Enterobacteriaceae to truly become pan-drug resistant. Moreover, multiple ARGs are often co-localized on the same plasmid, which allows for the relatively easy spread of multidrug resistance.

\section{Transformation}

In 1928, Griffith became the first to demonstrate direct genetic exchange between different strains of Streptococcus pneumoniae (Griffith, 1928). Certain bacteria appeared to be capable of uptake, integration, and functional expression of naked fragments of extracellular DNA, a process called (natural) transformation. It soon became clear that bacteria could use transformation to evade antibiotics, by exchanging ARGs. In 
A

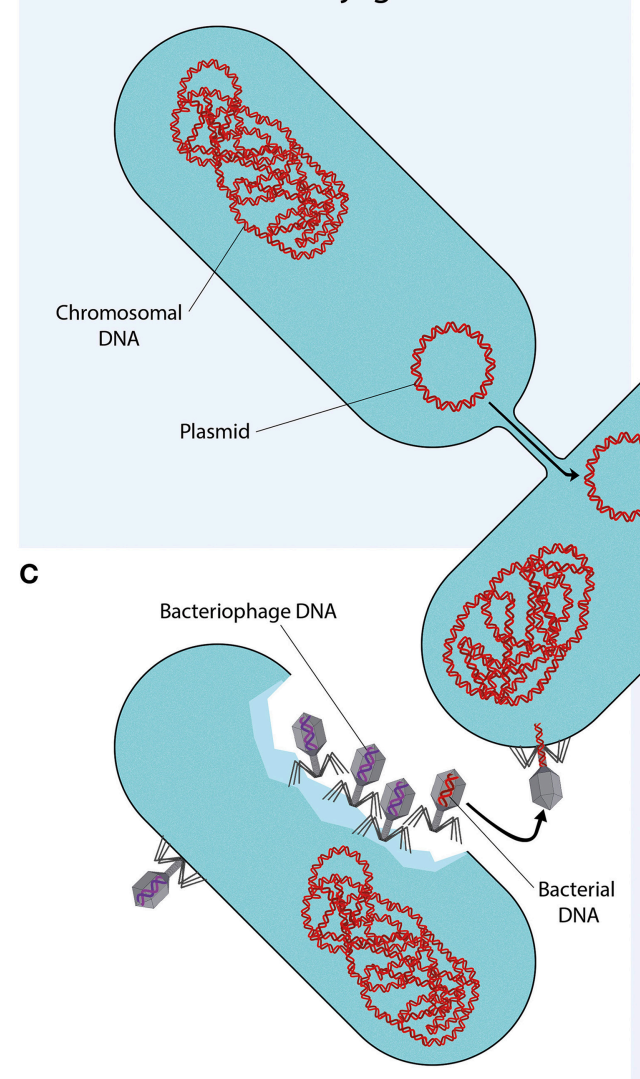

Transduction
B

\section{Transformation}

FIGURE 1 | Mechanisms of horizontal gene transfer. Each quadrant represents one different method of gene transfer. (A) Conjugation is a process requiring cell to cell contact via cell surface pili or adhesins, through which DNA is transferred from the donor cell to the recipient cell. (B) Transformation is the uptake, integration, and functional expression of naked fragments of extracellular DNA. (C) Through specialized or generalized transduction, bacteriophages may transfer bacterial DNA from a previously infected donor cell to the recipient cell. During generalized transduction, bacterial DNA may be accidentally loaded into the phage head (shown as a phage with a red DNA strand). During specialized transduction, genomic DNA neighboring the prophage DNA is co-excised and loaded into a new phage (not shown). (D) Gene transfer agents (GTAs) are bacteriophage-like particles that carry random pieces of the producing cell's genome. GTA particles may be released through cell lysis and spread to a recipient cell.

1951, Hotchkiss induced penicillin and streptomycin resistance in previously sensitive strains of $S$. pneumoniae by exposing them to DNA from resistant strains (Hotchkiss, 1951). Alexander et al. furthered this work by demonstrating intra- and interspecies transfer of streptomycin resistance between $H$. influenzae, $H$. parainfluenzae, and $H$. suis (Alexander and Leidy, 1953; Alexander et al., 1956).

In order for transformation to take place, several conditions have to be met. There must be DNA present in the extracellular environment; the recipient bacteria must be in a state of competence; and the translocated DNA must be stabilized, either by integration into the recipient genome, or by recircularisation (in the case of plasmid DNA) (Thomas and Nielsen, 2005). Whereas Neisseria spp. are considered to be constitutively competent (Sparling, 1966; Johnston et al., 2014), other bacterial species capable of natural transformation may develop competence only under certain conditions, such as the presence of peptides or autoinducers, nutritional status, or other stressful conditions, as reviewed in more detail by Johnston et al. (2014). Importantly, studies have shown that exposure to antibiotics can induce competence in many species of bacteria, meaning that antibiotics would not only select for resistant strains, but also stimulate transformation of their ARGs (Prudhomme et al., 2006; Charpentier et al., 2011, 2012).

In vitro experiments have done much to elucidate transformation of ARGs. Early work proved that ARGs could be transformed; to this end, streptomycin, rifampicin, erythromycin, nalidixic acid, and kanamycin resistance have variously been transformed into Neisseria gonorrhoeae (Sparling, 1966), Bacillus spp. (Harford and Mergeay, 1973), Gallibacterium anatis (Kristensen et al., 2012), and S. pneumoniae (Prudhomme et al., 2006). The introduction of molecular techniques allowed 
for the identification of the ARGs being transformed. In vitro studies have shown that the genes parC and gyrA are involved in the transformation of fluoroquinolone resistance between S. pneumoniae (Ferrandiz et al., 2000) and several viridans streptococci (Gonzalez et al., 1998; Janoir et al., 1999), and that transformation of penA confers penicillin resistance in commensal Neisseria species (N. flavescens and N. cinerea) and N. meningitidis (Bowler et al., 1994).

Molecular techniques have also made it possible to look for evidence of transformation outside of the laboratory. Spratt et al. identified the penA variant responsible for penicillin resistance in clinical isolates of $N$. gonorrhoeae (Spratt, 1988); sequence analysis revealed a mosaic structure, with blocks homologous to susceptible-type penA and blocks that diverge significantly (Spratt et al., 1992). These "resistant blocks" could be traced back to a strain of $N$. flavescens that had been isolated in the pre-antibiotic era, suggesting that such commensal species could have been the original source for the now ubiquitous resistance to penicillin (Spratt et al., 1989; Lujan et al., 1991). Mosaic genes are formed when sections of foreign DNA are incorporated into a recipient genome, as is the case in transformation. Their presence implies that HGT has taken place (Hakenbeck, 1998). In streptococci, the mosaic penicillin-binding protein (PBP) genes that encode PBPs with decreased affinity for $\beta$-lactam antibiotics are believed to be the result of gene transfer from related penicillin-resistant species (Sibold et al., 1994) and have disseminated penicillin resistance between various streptococci species (Dowson et al., 1990). Studies of fluoroquinolone resistance have demonstrated that mosaic variants of the genes parC, parE, and gyrA are readily transformed between $S$. pneumoniae, Streptococcus mitis and Streptococcus oralis (Balsalobre et al., 2003), and between Streptococcus pyogenes and Streptococcus dysgalactiae (Pletz et al., 2006).

Mao et al. developed a technique to extract intra- and extracellular DNA separately from environmental samples, and applied it to samples from a river basin in China. The resulta greater abundance of DNA outside of cells than insideimplies that in certain environments, extracellular DNA is a large reservoir for genes which may be accessible via transformation (Mao et al., 2014). Furthermore, Domingues et al. demonstrated that MGEs such as transposons, integrons and gene cassettes can be disseminated efficiently between species, regardless of their level of genetic relatedness (Domingues et al., 2012). Similarly, streptococcal species have been shown to exchange conjugative transposons via transformation in addition to conjugation (Chancey et al., 2015). All of this indicates that transformation provides a broad capacity for the horizontal spread of resistance elements between divergent species.

\section{Transduction}

Bacteriophages play an important role in shaping the bacterial microbiome in any environment. Through specialized or generalized transduction, bacteriophages can transfer genes that are advantageous to their microbial hosts, in turn promoting their own survival and dissemination (Modi et al., 2013). The transferable DNA sequences range from chromosomal DNA to MGEs such as plasmids, transposons and genomic islands (Brown-Jaque et al., 2015).

The mobilization or transfer of ARGs by bacteriophages has been documented for various bacterial species: the transduction of erythromycin (Hyder and Streitfeld, 1978), tetracycline or multiple resistances between strains of $S$. pyogenes (Ubukata et al., 1975); the transfer of tetracycline and gentamicin resistance between enterococci (Mazaheri Nezhad Fard et al., 2011); the carriage of $\beta$-lactamase genes by bacteriophages in Escherichia coli (Billard-Pomares et al., 2014) and Salmonella (Schmieger and Schicklmaier, 1999); or the transfer of antibiotic resistance plasmids in MRSA (Varga et al., 2012).

Recent studies applying metagenomic approaches to samples from various environments have suggested that bacteriophages may play a bigger part in the spread of ARGs than previously recognized. Colomer-Lluch et al. used qPCR to show that the $\beta$-lactam ARGs bla $a_{\mathrm{TEM}}, b l a_{\mathrm{CTX}-\mathrm{M}}$ and $m e c A$ were present in bacteriophages from river and urban sewage water samples. Additionally, cloning of the phage DNA into ampicillin susceptible $E$. coli hosts resulted in resistant transformants, harboring either the $b l a_{\mathrm{TEM}}, b l a_{\mathrm{CTX}-\mathrm{M}}$, or undetermined ARGs (Colomer-Lluch et al., 2011a). In another study, the presence of ARGs in bacteriophages was detected in respiratory tract DNA of cystic fibrosis patients (Rolain et al., 2011). Modi et al. demonstrated that treatment with antibiotics increased the number of ARGs in the intestinal phageome of mice and expanded the interactions between phage and bacterial species (Modi et al., 2013), which is an important observation considering the increased environmental exposure to antibiotics discussed earlier. Furthermore, several studies have used qPCR to detect ARGs in bacteriophages from wastewater samples (Colomer-Lluch et al., 2014a,b), animal and human fecal samples (Colomer-Lluch et al., 2011b; Quiros et al., 2014), wastewater and sludge derived from wastewater treatment plants (CaleroCaceres et al., 2014), and hospital and wastewater treatment plant effluents (Marti et al., 2014), indicating that bacteriophages are significant reservoirs of ARGs. Shousha et al. investigated bacteriophages isolated from chicken meat and found that about a quarter of the randomly isolated bacteriophages were able to transduce resistance to one or more antibiotics into an E. coli host. Moreover, they found a significant relationship between the presence of bacteriophages transducing kanamycin ARGs, and $E$. coli isolates resistant to kanamycin, implying a possible role of this mechanism in the spread of AMR (Shousha et al., 2015).

Considering certain bacteriophages have been reported to have a wide host range that crosses between different species (Mazaheri Nezhad Fard et al., 2011) or even different taxonomic classes (Jensen et al., 1998), the observation of the plethora of ARGs carried by bacteriophages in various bacterial communities and environments provides renewed insights into the role of transduction in the dissemination of ARGs in microbial ecosystems.

\section{Gene Transfer Agents}

Gene transfer agents (GTAs), first identified in Rhodobacter capsulatus (RcGTA) in 1974 (Marrs, 1974), are host-cell produced particles that resemble bacteriophage structures, capable of 
transferring genetic content. GTAs have several characteristic features: (i) rather than carrying DNA encoding their own machinery (as with self-propagating bacteriophages), GTAs carry random pieces of the producing cell's genome (Marrs, 1974; Humphrey et al., 1997; Stanton, 2007; Hynes et al., 2012); (ii) the amount of DNA packaged by the GTAs is insufficient to encode all of their protein components, making them unable to self-propagate (Lang and Beatty, 2000, 2001, 2007); (iii) GTA production is controlled by cell regulatory mechanisms (Lang and Beatty, 2000; Leung et al., 2012; Mercer et al., 2012; Brimacombe et al., 2014); (iv) GTA particles are released through cell lysis (Hynes et al., 2012; Westbye et al., 2013) although cultures do not display observable lysis (Marrs, 1974) as only a small subpopulation of GTA-producing cultures $(\sim 3 \%)$ is responsible for $\sim 95 \%$ of GTA release (Fogg et al., 2012; Hynes et al., 2012); (v) recently, it has been proposed that GTAs combine key aspects of transduction and transformation for cell entry, requiring proteins involved in natural transformation (Brimacombe et al., 2015).

Although GTA particles do not necessarily carry any GTA-encoding genes (Lang et al., 2012), RcGTA-like gene clusters are widespread in alphaproteobacteria, especially in the Rhodobacterales: a complete set of RcGTA-like structural genes has been demonstrated in nearly every sequenced member of the Rhodobacterales (Lang and Beatty, 2007; Lang et al., 2012). Moreover, two species in the order of Rhodobacterales, Roseovarius nubinhibens and Ruegeria mobilis, are known to produce GTAs, and there is evidence of GTA production in Ruegeria pomeroyi (Biers et al., 2008; McDaniel et al., 2010; Lang et al., 2012). Other known GTAs are VSH-1 in the spirochaete Brachyspira hyodysenteriae, Dd1 in the deltaproteobacterium Desulfovibrio desulfuricans, and VTA in the archaeon Methanococcus voltae (Lang and Beatty, 2007; Lang et al., 2012). The genes required for GTA-production are contained within the host genome and appear to have been propagated through vertical transmission (Lang and Beatty, 2007).

It has been suggested that GTAs have several advantages over the previously described mechanisms of HGT (Stanton, 2007): GTA particles afford DNA protection from damaging environmental factors, as opposed to the naked DNA involved in natural transformation; compared to conjugation, the transfer ability of GTAs is likely maintained after conditions killing the host cell, and is moreover not constrained by cell-tocell contact; lastly, compared to transduction, GTA particles predominantly carry random pieces of host genome, rather than mostly bacteriophage DNA. In the marine environment, GTAmediated transfer events have been reported to be remarkably high; up to several million times higher than previous estimates

\section{REFERENCES}

Alexander, H. E., Hahn, E., and Leidy, G. (1956). On the specificity of the desoxyribonucleic acid which induces streptomycin resistance in Hemophilus. J. Exp. Med. 104, 305-320. doi: 10.1084/jem.104.3.305

Alexander, H. E., and Leidy, G. (1953). Induction of streptomycin resistance in sensitive Hemophilus influenzae by extracts containing desoxyribonucleic of HGT in marine environments, exceeding previously described transformation and transduction frequencies (McDaniel et al., 2010). Moreover, genes can be exchanged between bacterial phyla (McDaniel et al., 2010; Lang et al., 2012), suggesting the possible widespread contribution of GTAs in shaping and driving adaptation of the natural environment.

In culture, GTA mediated transfer of antibiotic resistance markers has been readily demonstrated in R. capsulatus (Marrs, 1974; Solioz et al., 1975; Wall et al., 1975) and the spirochaete Brachyspira hyodesenteriae (Stanton et al., 2001, 2008). Moreover, GTAs have been used to transfer traits from plasmids (Scolnik and Haselkorn, 1984). In addition, the B. hyodesenteriae GTA VSH-1 can be induced by certain antibiotics (Stanton et al., 2008), which points out its possible impact in its natural environment, the swine intestinal tract. Other Brachyspira spp. occur in the intestinal tract of other species, including humans and chickens (Hampson and Ahmed, 2009), in which VSH-1 genes have been described (Motro et al., 2009). However, interspecies GTA-mediated transfer remains to be demonstrated (Motro et al., 2009).

The impact of GTAs on human health has yet to be established, but given the high frequency of transfer events in certain environments, and their ability to exchange genes between phyla, their potential to act as vehicles of resistance traits in the environment, and within the microbiota of humans and farmed animals is an area worthy of further study.

\section{CONCLUSION}

The increase in environmental levels of antibiotics, driven by medical and agricultural demand, is unprecedented and has disrupted the natural balance between microbes and antimicrobials. The effects this has on microbial communities are wide-ranging, and the result is an increasingly tangible threat to healthcare, as resistance to all known antibiotics disseminates rapidly around the globe. Our knowledge of the interactions between antimicrobials and resistance against it, observed not only in the clinic but across different ecosystems around the world, is rapidly increasing and has provided valuable insights. However, it is vital that we continue to unravel the extent of, and dissemination between resistomes of these microbial ecosystems, as any attempt at coming to terms with the AMR problem will have to account for these vast reservoirs of ARGs.

\section{AUTHOR CONTRIBUTIONS}

CW, JN, SM wrote the article. CW, JN made the Figure. JP, LA, PS, PW provided feedback and discussion on the article. ISME J. 3, 243-251. doi: 10.1038/ismej.2008.86

Aminov, R. I. (2009). The role of antibiotics and antibiotic resistance in nature. Environ. Microbiol. 11, 2970-2988. doi: 10.1111/j.1462-2920.2009.01972.x 
Arcilla, M. S., van Hattem, J. M., Matamoros, S., Melles, D. C., Penders, J., de Jong, M. D., et al. (2015). Dissemination of the $\mathrm{mcr}-1$ colistin resistance gene. Lancet Infect. Dis. 16, 147-149. doi: 10.1016/S1473-3099(15)00541-1

Balsalobre, L., Ferrandiz, M. J., Linares, J., Tubau, F., and de la Campa, A. G. (2003). Viridans group streptococci are donors in horizontal transfer of topoisomerase IV genes to Streptococcus pneumoniae. Antimicrob. Agents Chemother. 47, 2072-2081. doi: 10.1128/AAC.47.7.2072-2081.2003

Barlow, M., and Hall, B. G. (2002). Phylogenetic analysis shows that the OXA $\beta$ lactamase genes have been on plasmids for millions of years. J. Mol. Evol. 55, 314-321. doi: 10.1007/s00239-002-2328-y

Bhullar, K., Waglechner, N., Pawlowski, A., Koteva, K., Banks, E. D., Johnston, M. D., et al. (2012). Antibiotic resistance is prevalent in an isolated cave microbiome. PLoS ONE 7:e34953. doi: 10.1371/journal.pone.0034953

Biers, E. J., Wang, K., Pennington, C., Belas, R., Chen, F., and Moran, M. A. (2008). Occurrence and expression of gene transfer agent genes in marine bacterioplankton. Appl. Environ. Microbiol. 74, 2933-2939. doi: 10.1128/AEM.02129-07

Billard-Pomares, T., Fouteau, S., Jacquet, M. E., Roche, D., Barbe, V., Castellanos, M., et al. (2014). Characterization of a P1-like bacteriophage carrying an SHV2 extended-spectrum $\beta$-lactamase from an Escherichia coli strain. Antimicrob. Agents Chemother. 58, 6550-6557. doi: 10.1128/AAC.03183-14

Bowler, L. D., Zhang, Q. Y., Riou, J. Y., and Spratt, B. G. (1994). Interspecies recombination between the penA genes of Neisseria meningitidis and commensal Neisseria species during the emergence of penicillin resistance in N. meningitidis: natural events and laboratory simulation. J. Bacteriol. 176, 333-337.

Brimacombe, C. A., Ding, H., and Beatty, J. T. (2014). Rhodobacter capsulatus DprA is essential for RecA-mediated gene transfer agent (RcGTA) recipient capability regulated by quorum-sensing and the CtrA response regulator. Mol. Microbiol. 92, 1260-1278. doi: 10.1111/mmi.12628

Brimacombe, C. A., Ding, H., Johnson, J. A., and Beatty, J. T. (2015). Homologues of genetic transformation DNA import genes are required for Rhodobacter capsulatus gene transfer agent recipient capability regulated by the response regulator CtrA. J. Bacteriol. 197, 2653-2663. doi: 10.1128/JB.00332-15

Brown-Jaque, M., Calero-Caceres, W., and Muniesa, M. (2015). Transfer of antibiotic-resistance genes via phage-related mobile elements. Plasmid 79, 1-7. doi: 10.1016/j.plasmid.2015.01.001

Cabello, F. C. (2006). Heavy use of prophylactic antibiotics in aquaculture: a growing problem for human and animal health and for the environment. Environ. Microbiol. 8, 1137-1144. doi: 10.1111/j.1462-2920.2006.01054.x

Calero-Caceres, W., Melgarejo, A., Colomer-Lluch, M., Stoll, C., Lucena, F., Jofre, J., et al. (2014). Sludge as a potential important source of antibiotic resistance genes in both the bacterial and bacteriophage fractions. Environ. Sci. Technol. 48, 7602-7611. doi: 10.1021/es501851s

Canton, R., and Coque, T. M. (2006). The CTX-M $\beta$-lactamase pandemic. Curr. Opin. Microbiol. 9, 466-475. doi: 10.1016/j.mib.2006.08.011

Canton, R., Gonzalez-Alba, J. M., and Galan, J. C. (2012). CTX-M enzymes: origin and diffusion. Front. Microbiol. 3:110. doi: 10.3389/fmicb.2012.00110

Carattoli, A. (2013). Plasmids and the spread of resistance. Int. J. Med. Microbiol. 303, 298-304. doi: 10.1016/j.ijmm.2013.02.001

Card, R. M., Warburton, P. J., MacLaren, N., Mullany, P., Allan, E., and Anjum, M. F. (2014). Application of microarray and functional-based screening methods for the detection of antimicrobial resistance genes in the microbiomes of healthy humans. PLoS ONE 9:e86428. doi: 10.1371/journal.pone. 0086428

Chancey, S. T., Agrawal, S., Schroeder, M. R., Farley, M. M., Tettelin, H., and Stephens, D. S. (2015). Composite mobile genetic elements disseminating macrolide resistance in Streptococcus pneumoniae. Front. Microbiol. 6:26. doi: 10.3389/fmicb.2015.00026

Charpentier, X., Kay, E., Schneider, D., and Shuman, H. A. (2011). Antibiotics and UV radiation induce competence for natural transformation in Legionella pneumophila. J. Bacteriol. 193, 1114-1121. doi: 10.1128/JB.01146-10

Charpentier, X., Polard, P., and Claverys, J. P. (2012). Induction of competence for genetic transformation by antibiotics: convergent evolution of stress responses in distant bacterial species lacking SOS? Curr. Opin. Microbiol. 15, 570-576. doi: 10.1016/j.mib.2012.08.001

Cheng, G., Hu, Y., Yin, Y., Yang, X., Xiang, C., Wang, B., et al. (2012). Functional screening of antibiotic resistance genes from human gut microbiota reveals a novel gene fusion. FEMS Microbiol. Lett. 336, 11-16. doi: 10.1111/j.15746968.2012.02647.x

Clemente, J. C., Pehrsson, E. C., Blaser, M. J., Sandhu, K., Gao, Z., Wang, B., et al. (2015). The microbiome of uncontacted Amerindians. Sci. Adv. 1:e1500183. doi: $10.1126 /$ sciadv. 1500183

Colomer-Lluch, M., Calero-Caceres, W., Jebri, S., Hmaied, F., Muniesa, M., and Jofre, J. (2014a). Antibiotic resistance genes in bacterial and bacteriophage fractions of Tunisian and Spanish wastewaters as markers to compare the antibiotic resistance patterns in each population. Environ. Int. 73, 167-175. doi: 10.1016/j.envint.2014.07.003

Colomer-Lluch, M., Imamovic, L., Jofre, J., and Muniesa, M. (2011b). Bacteriophages carrying antibiotic resistance genes in fecal waste from cattle, pigs, and poultry. Antimicrob. Agents Chemother. 55, 4908-4911. doi: 10.1128/AAC.00535-11

Colomer-Lluch, M., Jofre, J., and Muniesa, M. (2011a). Antibiotic resistance genes in the bacteriophage DNA fraction of environmental samples. PLoS ONE 6:e17549. doi: 10.1371/journal.pone.0017549

Colomer-Lluch, M., Jofre, J., and Muniesa, M. (2014b). Quinolone resistance genes (qnrA and qnrS) in bacteriophage particles from wastewater samples and the effect of inducing agents on packaged antibiotic resistance genes. J. Antimicrob. Chemother. 69, 1265-1274. doi: 10.1093/jac/dkt528

Datta, N., and Hughes, V. M. (1983). Plasmids of the same Inc groups in Enterobacteria before and after the medical use of antibiotics. Nature. 306, 616-617. doi: 10.1038/306616a0

Davies, J. (2006). Are antibiotics naturally antibiotics? J. Ind. Microbiol. Biotechnol. 33, 496-499. doi: 10.1007/s10295-006-0112-5

Davison, J. (1999). Genetic exchange between bacteria in the environment. Plasmid 42, 73-91. doi: 10.1006/plas.1999.1421

D’Costa, V. M., King, C. E., Kalan, L., Morar, M., Sung, W. W., Schwarz, C., et al. (2011). Antibiotic resistance is ancient. Nature 477, 457-461. doi: 10.1038 /nature 10388

D'Costa, V. M., McGrann, K. M., Hughes, D. W., and Wright, G. D. (2006). Sampling the antibiotic resistome. Science 311, 374-377. doi: $10.1126 /$ science. 1120800

Domingues, S., Harms, K., Fricke, W. F., Johnsen, P. J., da Silva, G. J., and Nielsen, K. M. (2012). Natural transformation facilitates transfer of transposons, integrons and gene cassettes between bacterial species. PLoS Pathog. 8:e1002837. doi: 10.1371/journal.ppat.1002837

Donato, J. J., Moe, L. A., Converse, B. J., Smart, K. D., Berklein, F. C., McManus, P. S., et al. (2010). Metagenomic analysis of apple orchard soil reveals antibiotic resistance genes encoding predicted bifunctional proteins. Appl. Environ. Microbiol. 76, 4396-4401. doi: 10.1128/AEM. 01763-09

Dowson, C. G., Hutchison, A., Woodford, N., Johnson, A. P., George, R. C., and Spratt, B. G. (1990). Penicillin-resistant viridans streptococci have obtained altered penicillin-binding protein genes from penicillin-resistant strains of Streptococcus pneumoniae. Proc. Natl. Acad. Sci. U.S.A. 87, 5858-5862. doi: $10.1073 /$ pnas.87.15.5858

Economou, V., and Gousia, P. (2015). Agriculture and food animals as a source of antimicrobial-resistant bacteria. Infect. Drug Resist. 8, 49-61. doi: 10.2147/IDR.S55778

Ferrandiz, M. J., Fenoll, A., Linares, J., and De La Campa, A. G. (2000). Horizontal transfer of parC and gyrA in fluoroquinolone-resistant clinical isolates of Streptococcus pneumoniae. Antimicrob. Agents Chemother. 44, 840-847. doi: 10.1128/AAC.44.4.840-847.2000

Fick, J., Soderstrom, H., Lindberg, R. H., Phan, C., Tysklind, M., and Larsson, D. G. (2009). Contamination of surface, ground, and drinking water from pharmaceutical production. Environ. Toxicol. Chem. 28, 2522-2527. doi: 10.1897/09-073.1

Fogg, P. C., Westbye, A. B., and Beatty, J. T. (2012). One for all or all for one: heterogeneous expression and host cell lysis are key to gene transfer agent activity in Rhodobacter capsulatus. PLoS ONE 7:e43772. doi: 10.1371/journal.pone.0043772

Forsberg, K. J., Reyes, A., Wang, B., Selleck, E. M., Sommer, M. O., and Dantas, G. (2012). The shared antibiotic resistome of soil bacteria and human pathogens. Science 337, 1107-1111. doi: 10.1126/science.1220761

Fouhy, F., Ogilvie, L. A., Jones, B. V., Ross, R. P., Ryan, A. C., Dempsey, E. M., et al. (2014). Identification of aminoglycoside and $\beta$-lactam resistance genes from 
within an infant gut functional metagenomic library. PLoS ONE 9:e108016. doi: 10.1371/journal.pone. 0108016

Gibson, M. K., Forsberg, K. J., and Dantas, G. (2015). Improved annotation of antibiotic resistance determinants reveals microbial resistomes cluster by ecology. ISME J. 9, 207-216. doi: 10.1038/ismej.2014.106

Gonzalez, I., Georgiou, M., Alcaide, F., Balas, D., Linares, J., and de la Campa, A. G. (1998). Fluoroquinolone resistance mutations in the parC, parE, and gyrA genes of clinical isolates of viridans group streptococci. Antimicrob. Agents Chemother. 42, 2792-2798.

Graham, D. W., Olivares-Rieumont, S., Knapp, C. W., Lima, L., Werner, D., and Bowen, E. (2011). Antibiotic resistance gene abundances associated with waste discharges to the Almendares River near Havana, Cuba. Environ. Sci. Technol. 45, 418-424. doi: 10.1021/es $102473 \mathrm{z}$

Griffith, F. (1928). The significance of pneumococcal types. J. Hyg. (Lond.) 27, 113-159. doi: $10.1017 /$ S0022172400031879

Guglielmini, J., de la Cruz, F., and Rocha, E. P. (2013). Evolution of conjugation and type IV secretion systems. Mol. Biol. Evol. 30, 315-331. doi: $10.1093 / \mathrm{molbev} / \mathrm{mss} 221$

Hakenbeck, R. (1998). Mosaic genes and their role in penicillinresistant Streptococcus pneumoniae. Electrophoresis 19, 597-601. doi: 10.1002/elps.1150190423

Hall, B. G., and Barlow, M. (2004). Evolution of the serine $\beta$-lactamases: past, present and future. Drug Resist. Updat. 7, 111-123. doi: 10.1016/j.drup.2004.02.003

Hampson, D. J., and Ahmed, N. (2009). Spirochaetes as intestinal pathogens: lessons from a Brachyspira genome. Gut Pathog. 1:10. doi: 10.1186/1757-47491-10

Harford, N., and Mergeay, M. (1973). Interspecific transformation of rifampicin resistance in the genus Bacillus. Mol. Gen. Genet. 120, 151-155. doi: $10.1007 / \mathrm{BF} 00267243$

Hartmann, A., Locatelli, A., Amoureux, L., Depret, G., Jolivet, C., Gueneau, E., et al. (2012). Occurrence of CTX-M Producing Escherichia coli in Soils, Cattle, and Farm Environment in France (Burgundy Region). Front. Microbiol. 3:83. doi: $10.3389 /$ fmicb. 2012.00083

Hawkey, P. M., and Jones, A. M. (2009). The changing epidemiology of resistance. J. Antimicrob. Chemother. 64(Suppl. 1), i3-i10. doi: 10.1093/jac/dkp256

Hotchkiss, R. D. (1951). Transfer of penicillin resistance in pneumococci by the desoxyribonucleate derived from resistant cultures. Cold Spring Harb. Symp. Quant. Biol. 16, 457-461. doi: 10.1101/SQB.1951.016.01.032

Hu, Y., Liu, F., Lin, I. Y., Gao, G. F., and Zhu, B. (2015). Dissemination of the mcr1 colistin resistance gene. Lancet Infect. Dis. 16, 146-147. doi: 10.1016/S14733099(15)00533-2

Huddleston, J. R. (2014). Horizontal gene transfer in the human gastrointestinal tract: potential spread of antibiotic resistance genes. Infect. Drug Resist. 7, 167-176. doi: 10.2147/IDR.S48820

Humphrey, S. B., Stanton, T. B., Jensen, N. S., and Zuerner, R. L. (1997). Purification and characterization of VSH-1, a generalized transducing bacteriophage of Serpulina hyodysenteriae. J. Bacteriol. 179, 323-329.

Hyder, S. L., and Streitfeld, M. M. (1978). Transfer of erythromycin resistance from clinically isolated lysogenic strains of Streptococcus pyogenes via their endogenous phage. J. Infect. Dis. 138, 281-286. doi: 10.1093/infdis/138.3.281

Hynes, A. P., Mercer, R. G., Watton, D. E., Buckley, C. B., and Lang, A. S. (2012). DNA packaging bias and differential expression of gene transfer agent genes within a population during production and release of the Rhodobacter capsulatus gene transfer agent, RcGTA. Mol. Microbiol. 85, 314-325. doi: 10.1111/j.1365-2958.2012.08113.x

Janoir, C., Podglajen, I., Kitzis, M. D., Poyart, C., and Gutmann, L. (1999). In vitro exchange of fluoroquinolone resistance determinants between Streptococcus pneumoniae and viridans streptococci and genomic organization of the parE-parC region in S. mitis. J. Infect. Dis. 180, 555-558. doi: 10.1086/ 314888

Jensen, E. C., Schrader, H. S., Rieland, B., Thompson, T. L., Lee, K. W., Nickerson, K. W., et al. (1998). Prevalence of broad-host-range lytic bacteriophages of Sphaerotilus natans, Escherichia coli, and Pseudomonas aeruginosa. Appl. Environ. Microbiol. 64, 575-580.

Johnston, C., Martin, B., Fichant, G., Polard, P., and Claverys, J. P. (2014). Bacterial transformation: distribution, shared mechanisms and divergent control. Nat. Rev. Microbiol. 12, 181-196. doi: 10.1038/nrmicro3199
Kazimierczak, K. A., Scott, K. P., Kelly, D., and Aminov, R. I. (2009). Tetracycline resistome of the organic pig gut. Appl. Environ. Microbiol. 75, 1717-1722. doi: 10.1128/AEM.02206-08

Knapp, C. W., Dolfing, J., Ehlert, P. A., and Graham, D. W. (2010). Evidence of increasing antibiotic resistance gene abundances in archived soils since 1940. Environ. Sci. Technol. 44, 580-587. doi: 10.1021/es901221x

Kristensen, B. M., Sinha, S., Boyce, J. D., Bojesen, A. M., Mell, J. C., and Redfield, R. J. (2012). Natural transformation of Gallibacterium anatis. Appl. Environ. Microbiol. 78, 4914-4922. doi: 10.1128/AEM.00412-12

Kristiansson, E., Fick, J., Janzon, A., Grabic, R., Rutgersson, C., Weijdegard, B., et al. (2011). Pyrosequencing of antibiotic-contaminated river sediments reveals high levels of resistance and gene transfer elements. PLOS ONE 6:e17038. doi: 10.1371/journal.pone. 0017038

Lang, A. S., and Beatty, J. T. (2000). Genetic analysis of a bacterial genetic exchange element: the gene transfer agent of Rhodobacter capsulatus. Proc. Natl. Acad. Sci. U.S.A. 97, 859-864. doi: 10.1073/pnas.97.2.859

Lang, A. S., and Beatty, J. T. (2001). The gene transfer agent of Rhodobacter capsulatus and "constitutive transduction" in prokaryotes. Arch. Microbiol. 175, 241-249. doi: 10.1007/s002030100260

Lang, A. S., and Beatty, J. T. (2007). Importance of widespread gene transfer agent genes in alpha-proteobacteria. Trends Microbiol. 15, 54-62. doi: 10.1016/j.tim.2006.12.001

Lang, A. S., Zhaxybayeva, O., and Beatty, J. T. (2012). Gene transfer agents: phage-like elements of genetic exchange. Nat. Rev. Microbiol. 10, 472-482. doi: 10.1038/nrmicro2802

Larsson, D. G., de Pedro, C., and Paxeus, N. (2007). Effluent from drug manufactures contains extremely high levels of pharmaceuticals. J. Hazard. Mater. 148, 751-755. doi: 10.1016/j.jhazmat.2007.07.008

Le-Minh, N., Khan, S. J., Drewes, J. E., and Stuetz, R. M. (2010). Fate of antibiotics during municipal water recycling treatment processes. Water Res. 44, 4295-4323. doi: 10.1016/j.watres.2010.06.020

Leung, M. M., Brimacombe, C. A., Spiegelman, G. B., and Beatty, J. T. (2012). The GtaR protein negatively regulates transcription of the gtaRI operon and modulates gene transfer agent (RcGTA) expression in Rhodobacter capsulatus. Mol. Microbiol. 83, 759-774. doi: 10.1111/j.1365-2958.2011.07963.x

Linares, J. F., Gustafsson, I., Baquero, F., and Martinez, J. L. (2006). Antibiotics as intermicrobial signaling agents instead of weapons. Proc. Natl. Acad. Sci. U.S.A. 103, 19484-19489. doi: 10.1073/pnas.0608949103

Liu, Y. Y., Wang, Y., Walsh, T. R., Yi, L. X., Zhang, R., Spencer, J., et al. (2015). Emergence of plasmid-mediated colistin resistance mechanism MCR1 in animals and human beings in China: a microbiological and molecular biological study. Lancet Infect. Dis. 16, 161-168. doi: 10.1016/S1473-3099(15) 00424-7

Lujan, R., Zhang, Q. Y., Saez Nieto, J. A., Jones, D. M., and Spratt, B. G. (1991). Penicillin-resistant isolates of Neisseria lactamica produce altered forms of penicillin-binding protein 2 that arose by interspecies horizontal gene transfer. Antimicrob. Agents Chemother. 35, 300-304. doi: 10.1128/AAC.35.2.300

Mao, D., Luo, Y., Mathieu, J., Wang, Q., Feng, L., Mu, Q., et al. (2014). Persistence of extracellular DNA in river sediment facilitates antibiotic resistance gene propagation. Environ. Sci. Technol. 48, 71-78. doi: 10.1021/es404280v

Marathe, N. P., Regina, V. R., Walujkar, S. A., Charan, S. S., Moore, E. R., Larsson, D. G., et al. (2013). A treatment plant receiving waste water from multiple bulk drug manufacturers is a reservoir for highly multi-drug resistant integronbearing bacteria. PLoS ONE 8:e77310. doi: 10.1371/journal.pone.0077310

Marrs, B. (1974). Genetic recombination in Rhodopseudomonas capsulata. Proc. Natl. Acad. Sci. U.S.A. 71, 971-973. doi: 10.1073/pnas.71.3.971

Marti, E., Variatza, E., and Balcazar, J. L. (2014). Bacteriophages as a reservoir of extended-spectrum $\beta$-lactamase and fluoroquinolone resistance genes in the environment. Clin. Microbiol. Infect. 20, O456-O459. doi: 10.1111/14690691.12446

Martinez, J. L. (2009). Environmental pollution by antibiotics and by antibiotic resistance determinants. Environ. Pollut. 157, 2893-2902. doi: 10.1016/j.envpol.2009.05.051

Martinez, J. L. (2008). Antibiotics and antibiotic resistance genes in natural environments. Science 321, 365-367. doi: 10.1126/science.1159483

Mazaheri Nezhad Fard, R., Barton, M. D., Heuzenroeder, M. W. (2011). Bacteriophage-mediated transduction of antibiotic resistance in enterococci. Lett. Appl. Microbiol. 52, 559-564. doi: 10.1111/j.1472-765X.2011.03043.x 
McDaniel, L. D., Young, E., Delaney, J., Ruhnau, F., Ritchie, K. B., and Paul, J. H. (2010). High frequency of horizontal gene transfer in the oceans. Science 330, 50. doi: 10.1126/science.1192243

Mercer, R. G., Quinlan, M., Rose, A. R., Noll, S., Beatty, J. T., and Lang, A. S. (2012). Regulatory systems controlling motility and gene transfer agent production and release in Rhodobacter capsulatus. FEMS Microbiol. Lett. 331, 53-62. doi: 10.1111/j.1574-6968.2012.02553.x

Meyer, R. (2009). Replication and conjugative mobilization of broad host-range IncQ plasmids. Plasmid 62, 57-70. doi: 10.1016/j.plasmid.2009.05.001

Modi, S. R., Lee, H. H., Spina, C. S., and Collins, J. (2013). Antibiotic treatment expands the resistance reservoir and ecological network of the phage metagenome. Nature 499, 219-222. doi: 10.1038/nature12212

Moore, A. M., Ahmadi, S., Patel, S., Gibson, M. K., Wang, B., Ndao, M. I., et al. (2015). Gut resistome development in healthy twin pairs in the first year of life. Microbiome 3:27. doi: 10.1186/s40168-015-0090-9

Moore, A. M., Patel, S., Forsberg, K. J., Wang, B., Bentley, G., Razia, Y., et al. (2013). Pediatric fecal microbiota harbor diverse and novel antibiotic resistance genes. PLoS ONE 8:e78822. doi: 10.1371/journal.pone.0078822

Mori, T., Mizuta, S., Suenaga, H., and Miyazaki, K. (2008). Metagenomic screening for bleomycin resistance genes. Appl. Environ. Microbiol. 74, 6803-6805. doi: 10.1128/AEM.00873-08

Motro, Y., La, T., Bellgard, M. I., Dunn, D. S., Phillips, N. D., and Hampson, D. (2009). Identification of genes associated with prophage-like gene transfer agents in the pathogenic intestinal spirochaetes Brachyspira hyodysenteriae, Brachyspira pilosicoli and Brachyspira intermedia. Vet. Microbiol. 134, 340-345. doi: 10.1016/j.vetmic.2008.09.051

Munck, C., Albertsen, M., Telke, A., Ellabaan, M., Nielsen, P. H., and Sommer, M. O. (2015). Limited dissemination of the wastewater treatment plant core resistome. Nat. Commun. 6, 8452. doi: 10.1038/ncomms9452

Musovic, S., Oregaard, G., Kroer, N., and Sorensen, S. J. (2006). Cultivationindependent examination of horizontal transfer and host range of an IncP1 plasmid among gram-positive and gram-negative bacteria indigenous to the barley rhizosphere. Appl. Environ. Microbiol. 72, 6687-6692. doi: 10.1128/AEM.00013-06

Nordmann, P., Dortet, L., and Poirel, L. (2012). Carbapenem resistance in Enterobacteriaceae: here is the storm! Trends Mol. Med. 18, 263-272. doi: 10.1016/j.molmed.2012.03.003

Norman, A., Hansen, L. H., and Sorensen, S. J. (2009). Conjugative plasmids: vessels of the communal gene pool. Philos. Trans. R. Soc. Lond. B Biol. Sci. 364, 2275-2289. doi: 10.1098/rstb.2009.0037

Parsley, L. C., Consuegra, E. J., Kakirde, K. S., Land, A. M., Harper, W. F. Jr., and Liles, M. R. (2010). Identification of diverse antimicrobial resistance determinants carried on bacterial, plasmid, or viral metagenomes from an activated sludge microbial assemblage. Appl. Environ. Microbiol. 76, 3753-3757. doi: 10.1128/AEM.03080-09

Pehrsson, E. C., Forsberg, K. J., Gibson, M. K., Ahmadi, S., and Dantas, G. (2013). Novel resistance functions uncovered using functional metagenomic investigations of resistance reservoirs. Front. Microbiol. 4:145. doi: 10.3389/fmicb. 2013.00145

Penders, J., and Stobberingh, E. E. (2008). Antibiotic resistance of motile aeromonads in indoor catfish and eel farms in the southern part of The Netherlands. Int. J. Antimicrob. Agents 31, 261-265. doi: 10.1016/j.ijantimicag.2007.10.002

Penders, J., Stobberingh, E. E., Savelkoul, P. H., and Wolffs, P. F. (2013). The human microbiome as a reservoir of antimicrobial resistance. Front. Microbiol. 4:87. doi: 10.3389/fmicb.2013.00087

Perron, G. G., Whyte, L., Turnbaugh, P. J., Goordial, J., Hanage, W. P., Dantas, G., et al. (2015). Functional characterization of bacteria isolated from ancient arctic soil exposes diverse resistance mechanisms to modern antibiotics. PLoS ONE 10:e0069533. doi: 10.1371/journal.pone. 0069533

Pletz, M. W., McGee, L., Van Beneden, C. A., Petit, S., Bardsley, M., Barlow, M., et al. (2006). Fluoroquinolone resistance in invasive Streptococcus pyogenes isolates due to spontaneous mutation and horizontal gene transfer. Antimicrob. Agents Chemother. 50, 943-948. doi: 10.1128/AAC.50.3.943-94 8.2006

Poirel, L., Liard, A., Rodriguez-Martinez, J. M., and Nordmann, P. (2005b). Vibrionaceae as a possible source of Qnr-like quinolone resistance determinants. J. Antimicrob. Chemother. 56, 1118-1121. doi: 10.1093/jac/dki371

Poirel, L., Potron, A., and Nordmann, P. (2012). OXA-48-like carbapenemases: the phantom menace. J. Antimicrob. Chemother. 67, 1597-1606. doi: $10.1093 / \mathrm{jac} / \mathrm{dks} 121$

Poirel, L., Rodriguez-Martinez, J. M., Mammeri, H., Liard, A., and Nordmann, P. (2005a). Origin of plasmid-mediated quinolone resistance determinant QnrA. Antimicrob. Agents Chemother. 49, 3523-3525. doi: 10.1128/AAC.49.8.35233525.2005

Prudhomme, M., Attaiech, L., Sanchez, G., Martin, B., and Claverys, J. P. (2006). Antibiotic stress induces genetic transformability in the human pathogen Streptococcus pneumoniae. Science 313, 89-92. doi: 10.1126/science.1127912

Quiros, P., Colomer-Lluch, M., Martinez-Castillo, A., Miro, E., Argente, M., Jofre, J., et al. (2014). Antibiotic resistance genes in the bacteriophage DNA fraction of human fecal samples. Antimicrob. Agents Chemother. 58, 606-609. doi: 10.1128/AAC.01684-13

Riesenfeld, C. S., Goodman, R. M., and Handelsman, J. (2004). Uncultured soil bacteria are a reservoir of new antibiotic resistance genes. Environ. Microbiol. 6, 981-989. doi: 10.1111/j.1462-2920.2004.00664.x

Rizzo, L., Manaia, C., Merlin, C., Schwartz, T., Dagot, C., Ploy, M. C., et al. (2013). Urban wastewater treatment plants as hotspots for antibiotic resistant bacteria and genes spread into the environment: a review. Sci. Total Environ. 447, 345-360. doi: 10.1016/j.scitotenv.2013.01.032

Roberts, A. P., and Mullany, P. (2009). A modular master on the move: the Tn916 family of mobile genetic elements. Trends Microbiol. 17, 251-258. doi: 10.1016/j.tim.2009.03.002

Rolain, J. M., Fancello, L., Desnues, C., and Raoult, D. (2011). Bacteriophages as vehicles of the resistome in cystic fibrosis. J. Antimicrob. Chemother. 66, 2444-2447. doi: 10.1093/jac/dkr318

Sarmah, A. K., Meyer, M. T., and Boxall, A. B. (2006). A global perspective on the use, sales, exposure pathways, occurrence, fate and effects of veterinary antibiotics (VAs) in the environment. Chemosphere 65, 725-759. doi: 10.1016/j.chemosphere.2006.03.026

Schmieger, H., and Schicklmaier, P. (1999). Transduction of multiple drug resistance of Salmonella enterica serovar typhimurium DT104. FEMS Microbiol. Lett. 170, 251-256. doi: 10.1111/j.1574-6968.1999.tb13381.x

Scolnik, P. A., and Haselkorn, R. (1984). Activation of extra copies of genes coding for nitrogenase in Rhodopseudomonas capsulata. Nature 307, 289-292. doi: $10.1038 / 307289 \mathrm{a} 0$

Shoemaker, N. B., Vlamakis, H., Hayes, K., and Salyers, A. A. (2001). Evidence for extensive resistance gene transfer among Bacteroides spp. and among Bacteroides and other genera in the human colon. Appl. Environ. Microbiol. 67, 561-568. doi: 10.1128/AEM.67.2.561-568.2001

Shousha, A., Awaiwanont, N., Sofka, D., Smulders, F. J., Paulsen, P., Szostak, M. P., et al. (2015). Bacteriophages isolated from chicken meat and the horizontal transfer of antimicrobial resistance genes. Appl. Environ. Microbiol. 81, 4600-4606. doi: 10.1128/AEM.00872-15

Sibold, C., Henrichsen, J., Konig, A., Martin, C., Chalkley, L., and Hakenbeck, R. (1994). Mosaic pbpX genes of major clones of penicillin-resistant Streptococcus pneumoniae have evolved from pbpX genes of a penicillin-sensitive Streptococcus oralis. Mol. Microbiol. 12, 1013-1023. doi: 10.1111/j.13652958.1994.tb01089.x

Smillie, C., Garcillan-Barcia, M. P., Francia, M. V., Rocha, E. P., and de la Cruz, F. (2010). Mobility of plasmids. Microbiol. Mol. Biol. Rev. 74, 434-452. doi: 10.1128/MMBR.00020-10

Solioz, M., Yen, H. C., and Marris, B. (1975). Release and uptake of gene transfer agent by Rhodopseudomonas capsulata. J. Bacteriol. 123, 651-657.

Sommer, M. O., Dantas, G., and Church, G. M. (2009). Functional characterization of the antibiotic resistance reservoir in the human microflora. Science 325 1128-1131. doi: 10.1126/science. 1176950

Sparling, P. F. (1966). Genetic transformation of Neisseria gonorrhoeae to streptomycin resistance. J. Bacteriol. 92, 1364-1371.

Spratt, B. G. (1988). Hybrid penicillin-binding proteins in penicillin-resistant strains of Neisseria gonorrhoeae. Nature 332, 173-176. doi: 10.1038/332173a0

Spratt, B. G., Bowler, L. D., Zhang, Q. Y., Zhou, J., and Smith, J. M. (1992). Role of interspecies transfer of chromosomal genes in the evolution of penicillin resistance in pathogenic and commensal Neisseria species. J. Mol. Evol. 34, 115-125. doi: 10.1007/BF00182388 
Spratt, B. G., Zhang, Q. Y., Jones, D. M., Hutchison, A., Brannigan, J. A., and Dowson, C. G. (1989). Recruitment of a penicillin-binding protein gene from Neisseria flavescens during the emergence of penicillin resistance in Neisseria meningitidis. Proc. Natl. Acad. Sci. U.S.A. 86, 8988-8992. doi: 10.1073/pnas.86.22.8988

Stanton, T. B. (2007). Prophage-like gene transfer agents-novel mechanisms of gene exchange for Methanococcus, Desulfovibrio, Brachyspira, and Rhodobacter species. Anaerobe 13, 43-49. doi: 10.1016/j.anaerobe.2007.03.004

Stanton, T. B., Humphrey, S. B., Sharma, V. K., and Zuerner, R. L. (2008). Collateral effects of antibiotics: carbadox and metronidazole induce VSH-1 and facilitate gene transfer among Brachyspira hyodysenteriae strains. Appl. Environ. Microbiol. 74, 2950-2956. doi: 10.1128/AEM.00189-08

Stanton, T. B., Matson, E. G., and Humphrey, S. B. (2001). Brachyspira (Serpulina) hyodysenteriae gyrB mutants and interstrain transfer of coumermycin A(1) resistance. Appl. Environ. Microbiol. 67, 2037-2043. doi: 10.1128/AEM.67.5.2037-2043.2001

Tamminen, M., Virta, M., Fani, R., and Fondi, M. (2012). Large-scale analysis of plasmid relationships through gene-sharing networks. Mol. Biol. Evol. 29, 1225-1240. doi: 10.1093/molbev/msr292

Tennstedt, T., Szczepanowski, R., Braun, S., Puhler, A., and Schluter, A. (2003). Occurrence of integron-associated resistance gene cassettes located on antibiotic resistance plasmids isolated from a wastewater treatment plant. FEMS Microbiol. Ecol. 45, 239-252. doi: 10.1016/S0168-6496(03)00164-8

Thomas, C. M., and Nielsen, K. M. (2005). Mechanisms of, and barriers to, horizontal gene transfer between bacteria. Nat. Rev. Microbiol. 3, 711-721. doi: 10.1038/nrmicro1234

Torres-Cortes, G., Millan, V., Ramirez-Saad, H. C., Nisa-Martinez, R., Toro, N., and Martinez-Abarca, F. (2011). Characterization of novel antibiotic resistance genes identified by functional metagenomics on soil samples. Environ. Microbiol. 13, 1101-1114. doi: 10.1111/j.1462-2920.2010.02422.x

Ubukata, K., Konno, M., and Fujii, R. (1975). Transduction of drug resistance to tetracycline, chloramphenicol, macrolides, lincomycin and clindamycin with phages induced from Streptococcus pyogenes. J. Antibiot. 28, 681-688. doi: 10.7164/antibiotics.28.681

Van Boeckel, T. P., Brower, C., Gilbert, M., Grenfell, B. T., Levin, S. A., Robinson, T. P., et al. (2015). Global trends in antimicrobial use in food animals. Proc. Natl. Acad. Sci. U.S.A. 112, 5649-5654. doi: 10.1073/pnas.1503141112

Van Boeckel, T. P., Gandra, S., Ashok, A., Caudron, Q., Grenfell, B. T., Levin, S. A., et al. (2014). Global antibiotic consumption 2000 to 2010: an analysis of national pharmaceutical sales data. Lancet Infect. Dis. 14, 742-750. doi: 10.1016/S1473-3099(14)70780-7

Varga, M., Kuntova, L., Pantucek, R., Maslanova, I., Ruzickova, V., and Doskar, J. (2012). Efficient transfer of antibiotic resistance plasmids by transduction within methicillin-resistant Staphylococcus aureus USA300 clone. FEMS Microbiol. Lett. 332, 146-152. doi: 10.1111/j.1574-6968.2012. 02589.x

Vien le, T. M., Minh, N. N., Thuong, T. C., Khuong, H. D., Nga, T. V., Thompson, C., et al. (2012). The co-selection of fluoroquinolone resistance genes in the gut flora of Vietnamese children. PLOS ONE 7:e42919. doi: 10.1371/journal.pone.0042919

von Wintersdorff, C. J., Penders, J., Stobberingh, E. E., Lashof, A. M., Hoebe, C. J., Savelkoul, P. H., et al. (2014). High rates of antimicrobial drug resistance gene acquisition after international travel, the Netherlands. Emerging Infect. Dis. 20, 649-657. doi: 10.3201/eid2004.131718

Wall, J. D., Weaver, P. F., and Gest, H. (1975). Gene transfer agents, bacteriophages, and bacteriocins of Rhodopseudomonas capsulata. Arch. Microbiol. 105, 217-224. doi: 10.1007/BF00447140

Watkinson, A. J., Murby, E. J., and Costanzo, S. D. (2007). Removal of antibiotics in conventional and advanced wastewater treatment: implications for environmental discharge and wastewater recycling. Water Res. 41, 4164-4176. doi: 10.1016/j.watres.2007.04.005

Westbye, A. B., Leung, M. M., Florizone, S. M., Taylor, T. A., Johnson, J. A., Fogg, P. C., et al. (2013). Phosphate concentration and the putative sensor kinase protein CckA modulate cell lysis and release of the Rhodobacter capsulatus gene transfer agent. J. Bacteriol. 195, 5025-5040. doi: 10.1128/JB.00669-13

Wichmann, F., Udikovic-Kolic, N., Andrew, S., and Handelsman, J. (2014). Diverse antibiotic resistance genes in dairy cow manure. MBio. 5:e01017. doi: 10.1128/mBio.01017-13

Woerther, P. L., Burdet, C., Chachaty, E., and Andremont, A. (2013). Trends in human fecal carriage of extended-spectrum $\beta$-lactamases in the community: toward the globalization of CTX-M. Clin. Microbiol. Rev. 26, 744-758. doi: 10.1128/CMR.00023-13

Wozniak, R. A., and Waldor, M. K. (2010). Integrative and conjugative elements: mosaic mobile genetic elements enabling dynamic lateral gene flow. Nat. Rev. Microbiol. 8, 552-563. doi: 10.1038/nrmicro2382

Wright, G. D. (2010). Antibiotic resistance in the environment: a link to the clinic? Curr. Opin. Microbiol. 13, 589-594. doi: 10.1016/j.mib.2010.08.005

Wright, G. D., and Poinar, H. (2012). Antibiotic resistance is ancient: implications for drug discovery. Trends Microbiol. 20, 157-159. doi: 10.1016/j.tim.2012.01.002

Zhang, X. X., Zhang, T., Zhang, M., Fang, H. H., and Cheng, S. P. (2009). Characterization and quantification of class 1 integrons and associated gene cassettes in sewage treatment plants. Appl. Microbiol. Biotechnol. 82, 1169-1177. doi: 10.1007/s00253-009-1886-y

Conflict of Interest Statement: The authors declare that the research was conducted in the absence of any commercial or financial relationships that could be construed as a potential conflict of interest.

Copyright (C) 2016 von Wintersdorff, Penders, van Niekerk, Mills, Majumder, van Alphen, Savelkoul and Wolfs. This is an open-access article distributed under the terms of the Creative Commons Attribution License (CC BY). The use, distribution or reproduction in other forums is permitted, provided the original author(s) or licensor are credited and that the original publication in this journal is cited, in accordance with accepted academic practice. No use, distribution or reproduction is permitted which does not comply with these terms. 